\title{
Internationalization and innovation: The case of a born global from Brazil
}

\author{
Thaisa Carolina Zonta ${ }^{1}$ and Mohamed Amal \\ Universidade Regional de Blumenau, FURB/PPGAD, Blumenau SC, Brazil
}

\begin{tabular}{l}
\hline ARTICLE DETAILS \\
\hline Article history: \\
Received: May 23, 2017 \\
Reviewed: October 07, 2017 \\
Accepted January 29, 2018 \\
Available online April 10, 2018 \\
Double Blind Review System \\
Scientifc Editor \\
Mariana Sutter
\end{tabular}

\section{Keywords:}

Born Global

Emerging Markets

Institutions

Internationalization

Innovation

\begin{abstract}
The significance of Born Global firms' study is increasing due to their early internationalization aspects, innovation and economic growth; however, most of existent studies are focused on developed markets. This is the reason why this study is addressed to analyze the internationalization effects on the innovation in a Born Global firm from emerging market. We have used the literature review about innovation, internationalization and Born Global from emerging markets, also an in-depth interview with the founder and the financial/administrative coordinator of a Brazilian Born Global company that have demonstrated a proactive internationalization behavior moving to the United States. The result shows that, the internationalization to a country with stable institutions affects positively the innovation of the firm, providing the possibility of exploring resources, resulting in financial growth, superior knowledge and capabilities. This research contributes for an improved knowledge of the phenomenon in the context of emerging markets. Also, the perspective of institutions in the host country, which determines the firm's innovation performance and finally, we explore the case of a firm from an emerging economy that moved to a developed country (South-North) to develop new capabilities and maintain its strategy of innovation.
\end{abstract}

C 2018 Internext | ESPM. All rights reserved!

\section{INTRODUCTION}

The new global environment is controlled by a rapid pace of technological changes; decreasing product life cycles, expanding customer demands, more productivity and quality necessities, also aggressive global competition (Evanschitzky, Eisend, Calantone, \& Jiang, 2012). As global economic competition becomes increasingly driven by technology and innovation, there has emerged a heightened interest in the technological advantage of nations (Porter, 1990). The determining factor of competitiveness has become the capacity to extent business across borders (Narula \& Hagedoorn, 1999).

In addition, global economic connection modified the competitive paradigm, demanding an international and innovation (Chetty \& Stangl, 2010) extension strategy to influence long-term growth and survival (Karagozoglou \& Lindell, 1998). According to these circumstances, a new type of firm was evidenced in the market. It is named Born Global due to its early and fast internationalization pathway and their challenge to the traditional stages of internationalization models (Cavusgil \& Knight, 2015; Rennie, 1993). BGs are encountered commonly in the high-technology sectors (Autio, George, \& Alexy, 2011) and because of this they have more propensity to internationalize rapidly (Chetty \& Stangl, 2010). Existing literature concentrate on the effect of the entrepreneur orientation, which is an association of innovative, proactive and risk-seeking behavior, on the internationalization of Born Global firms, expecting to generate value to the firms (Cavusgil \& Knight, 2015; Lumpkin \& Dess, 1996). On the other hand, this study is more focused on the effect of a BG's internationalization on its innovation and states 
that the entrepreneur who chooses to internationalize is more likely to innovate the activities and generating international growth.

Besides this, previous studies about BGs from emerging markets have been developed in some perspectives (Dib, Rocha, \& da Silva, 2010; Ribeiro, Scholar, Junior, \& Borini, 2012; Ribeiro \& Pimentel, 2009). However, research in this field are still scarce (Cavusgil, Knight \& Risenberger, 2012). Therefore, in order to expand this extent, it studies a BG from an emerging market (Brazil).

A technology-based company from an emerging market finds differences on the competitive and institutional context in a developed economy (Ribeiro, Lahiri, \& Borini, 2016). These firms face liabilities and with the purpose to survive and succeed, they need to develop legitimacy in the market (Zaheer, 1995). With the aim to identify the behavior of a BG firm in this context, we will attempt to investigate in depth the role of host country institutions in their innovation performance. Thus, the research question that we will address in this paper is the following: How does internationalization affect the innovation of a BG from emerging market? And in which extent host country institutions matter?

This article seeks to contribute to this purpose in several ways. First, we contribute for an improved knowledge of the phenomenon aiming at proposing new avenues on the studies about BG in the context of emerging markets. Secondly, we will address how institutions in the host country, where BGs operate, shape and determine their innovation performance. Finally, we will investigate the case of a firm from an emerging economy that has moved to a more developed country (South-North) to create new capabilities and sustain its strategy of innovation.

Besides the introduction, this article is organized in four more sections. In the following section, we present the theoretical background of the concepts and characteristics of innovation, internationalization and BG firms from emerging markets, and make some propositions for the analysis of our case study. In section three, the methodological procedures are discussed. Section four, we discuss our findings, and in section five, conclude our study by pointing to the main implications, theoretical and managerial, of our findings.

\section{LITERATURE REVIEW AND PROPOSITIONS}

The literature review considers distinct knowledge areas with the aim of assisting a suggested framework to support the propositions of the study.

\subsection{Innovation}

Innovation is fundamental to advanced and emerging economies, firms invest as much in the knowledgebased assets that drive innovation, such as software, databases, research and development, firm-specific skills and organizational capital, as they do in physical capital, such as machinery, equipment or buildings. The use of information and communication technologies has become worldwide in only a few decades and new applications emerge daily (OECD, 2015).

An innovation can be a new product or service, a new production process technology, a new structure or administrative system, a new plan or program pertaining to organizational members (Damanpour, 1991). Therefore, the concept of innovation by Schumpeter (1934) - or the realization of new combinations - is broad. He detailed his concept in five items: (1) the introduction of a new good, (2) the introduction of a new method of production, (3) the opening of a new market, (4) the opening of a new source of supplies and (5) the establishment of a new organization in any industry, such as creating a new monopoly (Nelson \& Winter, 1982).

The innovation process within a business is influenced by internal and external factors and they are shaped by actors and activities (Shearmur, 2011). Throughout the innovation development, ideas are transformed into new products or services, new process technologies, new organizational structures, or new managerial approaches (Damanpour \& Aravind, 2012). Scholars argue that innovations are growth strategy instruments for firms that seek to enter new markets, and they lead to an increase in the existing market share (Gunday et al., 2011). Also, innovativeness enables firms to respond rapidly to market changes or to act on market offers before their competitors (Zahra and Covin, 1995). It is important because rapid changes in technologies and increasing competition in global markets weaken the value added by existing products and services (Gunday et al., 2011). 


\subsection{Internationalization and Innovation}

We begin our view of internationalization and innovation from the role of the entrepreneurship, which is associated with novelty, the promotion of change, and expansion into new markets (Kyläheiko, Jantunen, Puumalainen, Saarenketo and Tuppura, 2011). The entrepreneurs' behavior/orientation, as defined by Lumpkin \& Dess (1996), is composed of factors that inspire the firm's risk-taking propensity, competitively aggressive action, proactive conducts, and confidence of frequent and extensive product innovation. Entrepreneurial firms use the growth strategy of launching new products or attracting new customers, or combining both. From this perspective, the firms which operate with product and international diversification hold an entrepreneurial endeavor determined to exploit new opportunities and use their resources. Since both forms of diversification (innovation-related new products/services and internationalization-related new markets) are established on resources and competencies, we understand that they must be in some way interrelated (Kyläheiko, et al., 2011).

Internationalization is considered as a strategy permitting the firm to exploit new opportunities outside of its domestic market. Therefore, both innovation activity and firm internationalization could be understood as Schumpeterian entrepreneurial activity determined by the skills, routines and capabilities assigned in the firm (Buckley, 2009a, 2009b; on the real-options-based strategy view in this context, see Li \& Rugman, 2007). As Lu and Beamish (2001) recognize internationalization such as a significant chance for growth and value creation.

In terms of growth strategies, Kyläheiko et al. (2011) suggest that most rapid-growth rate will be achieved through internationalization with new products, by using a combination of innovation and internationalization strategies. BGs are typical examples of companies that have achieved rapid growth with new innovative products (Pearce \& Papanastassiou, 2006). However, this kind of innovation-based growth strategy is not feasible for all companies because of innovation-related resource and capability limitations.

Proposition 1: Since internationalization can facilitate the access to new resources, its effect also may increase the innovation performance of firms.
Caves (1982) was one of the first to discuss that firms which expanded to other markets possessed greater returns to innovation. Smallbone, Leig, and North (1995) indicate that the reason for a firm to expand its international business is to enlarge the profitability and likewise its survival, as well, many researchers have shown that managers depend on international market penetration strategies to ensure growth sustainability (Bell, 1997). Besides this, internationalization gives the opportunity to learn new abilities in foreign markets (Hitt, Hoskisson, \& Kim, 1997). For Buckley (2009a; 2009b) internationalization could be interpreted as a strategy allowing the firm to exploit new profitable opportunities out of the domestic market.

Innovation improves and uses external knowledge capability to capture, assimilate and use external knowledge (Varis and Littunen, 2010). Internationally diversified firms can better use the resources available globally (Chen \& Jaw, 2014). The internationalization also induces the firm's skills to produce technological innovation (innovative capacity), developing better products and processes, faster and at lower prices, it also helps exploiting technological development, protect and appropriate the innovation (Boermans \& Roelfsema, 2015).

Internationalization is also able to promote innovative capacity by upgrading the knowledge accumulation process and increasing organizational learning. Consequently, highly international firm has the opportunity to innovate and at the same time learn (Baum, Schwens, \& Kabst, 2013). The firms with the ability to develop and launch new products, services, or innovative processes which are superior to their competitors attest a competitive advantage, preserving a return on investment and a strategic advance in long term (Chandra, Styles, \& Wilkinson, 2012). In addition to this, Kotabe \& Srinivasan (2002), confirms that a highly international firm has access to different markets around the world, so it can minimize the costs related to innovation, as well as buying materials and $R \& D$ inputs from a cheaper available source.

\subsection{Born Global from Emerging Markets}

The gradual internationalization model developed by Johanson and Vahlne (1977) recommends that a firm should develop itself in the domestic market, establish a solid home base and after these steps, with a later stage of life cycle, internationalize. This 
model also makes a distinction between psychic and physical distance including diversity in languages, cultures, political system (Johanson \& Vahlne, 1990, p.11). However, some companies assume a different way of internationalization; they do it right after their launch or some years later. In 1993, a research about Australian manufacturers delineated the first phenomenon which indicated that some firms were being born global (Rennie, 1993).

Born Globals are entrepreneurial start-ups that, from or near their inception, seek to derive a considerable proportion of their revenue from the sale of products in international markets (Knight \& Cavusgil, 2004). BGs display specific pattern of knowledge and capabilities, such as entrepreneurial and managerial knowledge (Cavusgil \& Knight 2015), competencies that cause early internationalization and sustainable, superior performance in foreign markets.

These firms also rely on unique product offerings, they are directing market segments that traditional multinational firms are not capable to attend because of the emerging nature of such segments and flexibility essential to rapidly gain market share within these segments (McDougall \& Oviatt, 2000). This favors smaller firms with innovative product, because of their flexibility in serving the emerging segments (Cavusgil \& Knight, 2015).

These companies which arrived late in the global market place, involve themselves in aggressive, proactive and risk-taking measures to match competitors (Lou \& Tung, 2007). Their main strategy is to raise their stock of critical resources instead of exploiting existing advantages. They possess highlevel network competences and as a result, they quickly overcome outsidership (Johanson \& Vahlne, 2009). As stated by Axelsson and Easton (2016), a network concerns groups of two or more connected exchange relationships.

Network relationships as well, are responsible for the variety of knowledge, which is essential to identify potential innovations (Rubach, 2013), and opportunities in international markets (Zander, McDougall-Covin, \& Rose, 2015).

Networks are also indispensable in the emerging market circumstance where institutions normally have a lower level of institutional infrastructure. They are also used to reduce uncertainty and acquire competitive advantages (Tracey \& Phillips, 2011; Wright, Filatotchev, Hoskisson, \& Peng, 2005).

Proposition 2: BGs use their networks to target different countries and acquire resources including innovations, in which they lead to accelerated internationalization.

The internationalization process of BGs is determined by the knowledge provided by their network ties, network ties supply them besides knowledge on markets, also clients abroad. BGs' competitive advantages are defined by their knowledge intensity (Cavusgil \& Knight, 2015).

Furthermore, networks contribute with respectively formal and informal operating structure within which individual teams undertake innovative activities (Andersson, Dasí, Mudambi, \& Pedersen, 2016). In addition, Monferrer, Blesa, \& Ripollés, 2014 demonstrated that having a high-quality information from networks, can serve as a source for business opportunities and innovative ideas. These cooperative business environments increase the level of innovation within the Born Global firm (Matsuo, 2006).

In addition, the host-country plays a central role for firms form emerging markets in sustaining political, legal, social and economic development, and so can induce the conduct of firm's entering and acting in this foreign context. The role of social, political, economic and legal system is addressed by the Institutional theory that configure the organizational behavior (North, 1990; Scott, 1995; Wright et al., 2005). Institutions are categorized into regulatory, normative and cognitive elements/ pillars and every one of these is able to influence firm legitimacy and so their survival (Scott, 1995). Legitimacy commonly refers to "a social judgement of acceptance, appropriateness, and desirability [that] enables organizations to access other resources needed to survive and grow" (Zimmerman \& Zeitz, 2002, p. 414).

Firms from emerging markets operate in environments characterized by under-developed institutions that constrain the development of internal capabilities for innovation (Cuervo-Cazurra, 2008 and Lou and Tung, 2007). Thus, previous research proposes that firms originating from weak institutional environment internationalize to seek more efficient institutions (Luo, Xue, \& Han, 2010) that enable them to develop their innovation 
performance and global competitiveness (Wu, Wang, Hong, Piperopoulos, \& Zhuo, 2016).

Advanced economies are very attractive to emerging market firms, since they look for resources opportunities for their accelerated international expansion. Also, BGs lack the ownership, location and internalization advantages of established firms, thus legitimacy is a key resource needed to gain access to needed resources (Bangara Freeman \& Schroeder., 2012).

Proposition 3: Born Global from emerging markets seek for developed economies to access resources and innovation in order to obtain legitimacy and accelerated internationalization.

A developed institutional environment stimulate innovation by providing what firms are not able to produce individually and by permitting firms to access various factors and innovation intermediaries, and build innovation-enhancing relationships (e.g., interfirm alliances and research collaborations) (Wu et al., 2016).

Furthermore, in developed host-country institutional environments, foreign firms can access or collaborate with high-qualified and experienced local talent (i.e. scientists, designers and engineers) which can improve the firm's innovation performance (Florida, 1997 and Tung, 2007). In addition, since the institutions of developed countries are also characterized by dynamic and competitive local business environments they induce foreign companies to constantly update their skills and sustain the competition to ensure future survival and growth (Li, Vertinsky, Zhang, 2013).

However, BGs need to learn how to overcome the costs of doing business abroad and mitigating the potential liabilities of newness (Mudambi \& Zahra, 2007), foreignness (Zaheer, 2002) emergingness (Madhok, 2009) and outsidership (Johanson \& Vahlne, 2009). Young companies are not well known in foreign markets, they encounter these liabilities and consequently must establish their legitimacy to customers, intermediaries, and competitors (Lumpkin \& Dess, 1996).

In order to survive in its domestic environment, get adapted to an advanced economy environment with its unfamiliar norms and practices and also establish legitimacy, the firms from emerging market need to be persistent, resilient and aggressive
(Bangara et al. 2012). Although, the entrepreneurial orientation helps internationalizing firms, dominate the resource limitations that frequently constrain an international expansion (Lu and Beamish, 2001).

Based on the literature review above we can summarize the relationships between internationalization and innovation performance by Born Global in Figure 1. We state that the access to networks in home countries can contribute significantly to entrepreneurial behavior and the accelerated path of internationalization. This process may facilitate the access by Born Global to specific resources and the building of new capabilities in the foreign market. This is very likely to occur in highly developed countries suggesting between southnorth approach internationalization to increase innovation performance (Cavusgil, Knight \& Riesenberger, 2012).

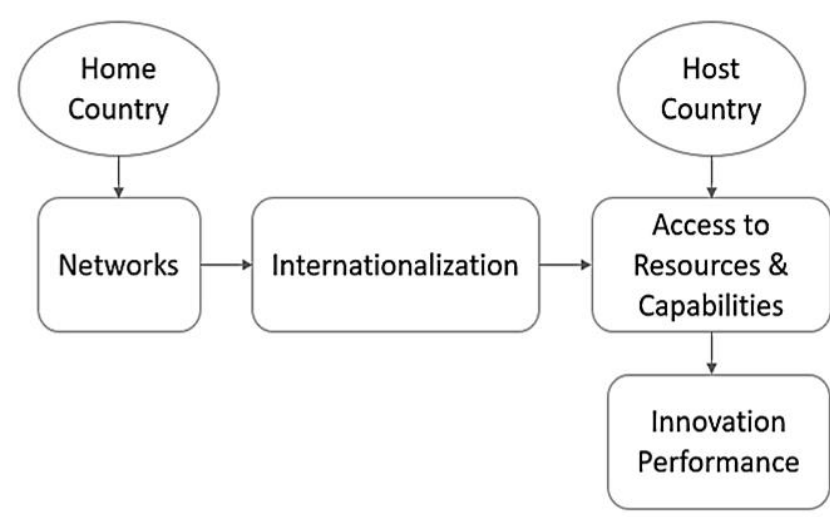

Fig. 1

Theoric model

Source: Research Data

\section{METHODOLOGICAL PROCEDURES}

In order to achieve the aim of this study, which is to analyze how internationalization affect the innovation of a BG from emerging market, the research method used is the qualitative exploratory. We adopt a case study method as stated in Eisenhardt's (1989) and Yin's (1989) approaches. The case studied in this research is selected by a few criteria as they follow, with the intention of understanding better the problem (Creswell, 2013); a) the firm must be a software company; $b$ ) it must be a small or medium enterprise which has a global vision; c) the headquarter of the firm must be located in an emerging market.

The case study is about the Easy Communication \& Technology firm, it was established in 2008 and went international in 2013, within 5 years after firm 
establishment. We selected the company for several reasons, first, it represents the typically case of accelerated internationalization, moving from Brazil, which represents very restricted and weak institutional environment for innovation, to a more developed country with more advanced institutions that support and facilitate the growth and innovation of firms (The United States). Second, the firm followed an internationalization path based on establishing a subsidiary in the host country and developing international transactions from this new platform.

The founder moved to the U.S.A and manages all the process from there. It is a technology service company based on six services such as design, sites development, software and mobile as well as video and automation. Therefore, the main company's businesses currently are sites development and personalized system development for medical area and laboratory.

It had the experience of being incubated for one year and a half, being interesting because of the network attained and the relationship built with the members of the other firms. In 2015, the company obtained 18 employees, the founder and five more employees live in Florida and the others in Brazil. The company's proposal is to have representatives in new developed markets, because of the economy, which have a great demand for its services and a strong currency, besides the language.

The subjects of the research are the founder situated in Fort Lauderdale and the commercial/administrative coordinator in São Paulo.

He is a very practical person who expects fast and assertive results from his employees. He has initiative to start projects and takes risks (Cui, Sun, Xiao, \& Zhao, 2016). He is not a bureaucratic person, he prefers to reduce the maximum number of contracts within the company (Hisrich \& Peters, 2004).

He also has ability to work intensely, even sleepless nights to deliver results (Markman \& Baron, 2003). It values creativity and innovation and opens the way for employees to participate, and points out suggestions. It is in constant search of personal knowledge and also of innovations for the company (Castaño, Méndez, \& Galindo, 2016). It has short, medium and long-term plans and looks for ways to achieve them (Picken, 2017).
The data collection is based on a guided in-depth interview (Yin, 2009) adapted from Wictor (2012).

The interview focused on how the internationalization affects the innovation in this BG from emerging market, also analyzing the role of networks, strategies used, knowledge, risks, uncertainties and legitimacy towards the developed market.

It was directed online via Hangouts on air, because of their availability and distance, it lasted about two hours. The data acquired from the interview was complemented with secondary material as videos and site's information.

The results of the interviews were analyzed based on the theoretical propositions of the research as suggested by Ghauri (2004). Also, a content analysis was used to complement the information (Yin, 2009). In Table 1 we present our research constructs, where we relate propositions to the categories and subcategories of analysis (Bardin, 2010).

The first category seeks to understand how the internationalization influences the innovation of BGs from emerging market, what are the opportunities it found in the process, the resources obtained in the new market, the new abilities acquired, also the benefits from the internationalization and innovation.

The second category is associated with the role of networks in the internationalization process, pursuing information about the networks the firm accessed before and during internationalization, also the importance they have, the knowledge developed through them and their contribution to the innovation.

The third category is related to the role of the institutions the firm encounters in the host market, looking forward to understanding the liabilities it faced, its influence on the innovation and the legitimacy role in this process.

The research data was validated using the triangulation based on interviews, available documents and secondary information accessed on the internet (Ghauri, 2004).

\section{RESULTS}

Considering the purpose of the study, which is to analyze how the internationalization affect the innovation of a BG from emerging market, the 
Tab. 1

Categories of analysis

\begin{tabular}{|c|c|c|c|}
\hline Propositions & $\begin{array}{c}\text { Categories of } \\
\text { Analysis }\end{array}$ & Sub categories & References \\
\hline $\begin{array}{c}\text { Since internationalization can facilitate } \\
\text { the access to new resources, its effects } \\
\text { also may increase the innovation } \\
\text { performance of firms. }\end{array}$ & $\begin{array}{l}\text { Internationalization } \\
\text { Innovation }\end{array}$ & $\begin{array}{l}\text { Opportunities exploitation/ } \\
\text { Resources/ Learning new } \\
\text { abilities / Benefits from } \\
\text { internationalization/ } \\
\text { Benefits from innovation }\end{array}$ & $\begin{array}{l}\text { Kyläheiko, et al., 2011; Lu \& } \\
\text { Beamish (2001); Pearce \& } \\
\text { Papanastassiou, 2006). }\end{array}$ \\
\hline $\begin{array}{l}\text { BGs use their networks to target many } \\
\text { countries and acquire resources } \\
\text { including innovations, in which they } \\
\text { lead to accelerated } \\
\text { internationalization. }\end{array}$ & $\begin{array}{l}\text { Networks/ } \\
\text { Entrepreneurial } \\
\text { Strategies }\end{array}$ & $\begin{array}{l}\text { Previous Networks/ } \\
\text { Networks in the process/ } \\
\text { Importance of Networks/ } \\
\text { Knowledge/ Contribution }\end{array}$ & $\begin{array}{l}\text { Andersson et al., 2016; Bangara } \\
\text { et al, 2012; Cavusgil \& Knight, } \\
\text { 2015; Monferrer et al., 2014; } \\
\text { Rubach, 2013; Zander et. al, 2015; }\end{array}$ \\
\hline $\begin{array}{l}\text { BGs from emerging markets seek for } \\
\text { developed economies to access } \\
\text { resources and innovation in order to } \\
\text { obtain legitimacy and accelerated } \\
\text { internationalization. }\end{array}$ & $\begin{array}{l}\text { Legitimacy/ } \\
\text { Credibility }\end{array}$ & $\begin{array}{l}\text { Political, legal, social and } \\
\text { economic development/ } \\
\text { liabilities/ Legitimacy }\end{array}$ & $\begin{array}{l}\text { Bangara et al., 2012; Johanson \& } \\
\text { Vahlne, 2009; Madhok, 2009; } \\
\text { Mudambi \& Zahra, 2007; North, } \\
\text { 1990; Scott, 1995; Zaheer, } 2002 .\end{array}$ \\
\hline
\end{tabular}

Source: Authors

analysis of content is used based on the elaborated propositions and developed focusing on the interpretation of the researcher.

In 2013 the founder went to the USA and detected the business opportunities in this area, he did not plan this internationalization; and did not have any knowledge about the process (Chandra et al., 2012). His main idea since the beginning was to open a company that could be global, although he always thought about quality of life, too. So, he moved to the U.S.A and the country selection was based on the culture, language, economy and the need of IT services.

Easy Communication and Technology uses the digital entrance to deliver its services (Lobo \& Whyte, 2017). This process of internationalization to the United States has contributed significantly to speed the economic growth of the firm. When Brazil was the main source of product development from 2008 to 2013 , the sales growth recorded a performance of $245 \%$, representing an annual average of about $50 \%$, in the period 2014/15 the company grew more than 420\% as can be shown in Table 1.

Tab. 2

Internationalization Path and Growth

\begin{tabular}{cccc}
\hline Date & Countries & Entry Mode & Sales Growth \\
\hline $2008 / 2013$ & Brazil & Home country & $245 \%$ \\
$2014 / 2015$ & U.S.A. & Digital entrance & $426 \%$
\end{tabular}

Source: Research data
Different companies contact it to develop a specific system for their necessities, the contact starts in the U.S.A, it is developed in Brazil and sent back to the U.S.A (Abbott, Zheng, Du, \& Willcocks, 2013). In Table 2 , the internationalization path and its growth are demonstrated.

The internationalization process took 3 days, the fact of being an IT company, the founder explained that the risk he could have, would only be to waste the money invested in that process in dollars, around two, three thousand dollars more than the usual per month, nothing else. The company adopted a proactive and aggressive strategy to enter the market, it selected the market and in short time it moved to Florida to test the experience, already spreading the services. BGs are entrepreneurial firms that give emphasis to aggressiveness, proactiveness innovativeness, and risk-taking (Cavusgil \& Knight, 2015).

Before the internationalization process, it had technical knowledge (previous knowledge and projects), management capabilities (videos and tutorials about training, so when they contracted someone, the person could study the material, without having anyone to teach) human resources and the language. These types of companies present specific knowledge and competences, for example entrepreneurial and managerial knowledge, aptitudes that induce early internationalization and sustainable, superior performance in foreign markets (García-García, García-Canal, \& Guillén, 2017). 
The company conquered many competitive advantages with the internationalization process, as the increase of the firm's revenue; the credibility towards the Brazilian companies improved; it has better quality in the services and processes; the founder obtained more knowledge, especially because in the U.S.A the technology moves faster; attained more experience with the market; they achieved stability due to the revenue growth and reliability for being in a developed market. The internationalization provides the chance to gain new expertise in foreign markets (Hitt et al., 1997).

The coordinator explained that, as the market is reliable, it brings the possibility of prospecting new plans and markets. Another advantage of internationalization it faced was the exchange rate, as it is so high in Brazil. Easy communication and Technology has bigger clients being in the U.S.A, it increased the knowledge and the quality of resources that it would not be able to have in Brazil, with the achievement of this knowledge and quality, it can repass to the Brazilian costumer with a lower price (Cavusgil \& Knight, 2015).

They consider it innovated after internationalizing due to the environment in which proposes high technology to the market, as well as having contact with networks to achieve clients and increase growth, being able to invest in the business. With these opportunities, the firm uses remote work, which brought a differential to the company, it also automates services through videos, human resource and recruitment, likewise the budget processes, since the projects are personalized. Hitt et al. (1997) remarks that innovation can be inspired using specific advantages of different countries. They added that these advantages are possible because of the IT field, not all the fields would be able to obtain these advantages and innovations. These types of innovations brought cost benefits for the company as cost reduction in salaries (Kim, Basu, Naidu, \& Cavusgil, 2011).

The company's proposal is to have representatives in new developed markets as Australia and England, these countries because of the economy, which have a great demand for its services and a strong currency, besides the language, in the future the ideas are to enter in other similar countries as Germany, Switzerland, and Japan with the same aspects.
The founder mentioned that Brazilian network in Florida is very strong because of the language. These networks were clients giving reference to other firms, he was invited to participate to the BNI foundation (Business Network International) which is the world's largest business networking and referral organization, as well the friendships he made with the Brazilian community, helped the business, so these are other advantages, besides the technical service differential (Coviello, 2006).

However, he did not have any network in the U.S.A before the process. He commented that he uses the network sites Facebook and Meet up to get involved in networks. He advises the importance of clients' networks, the knowledge about the accounting process, taxes information and bureaucracy before the process, also recommends that financial structure, investment funds, strong networks and knowledge about the accounting rules, are helpful in this process.

He faced barriers in the accounting and immigration aspects, he had to find the legal means to stay in the U.S.A and manage the company in both countries, as well as to be aware of the accounting processes. He has not found a helpful accountant to surpass this barrier, yet (Johanson \& Vahlne, 2009).

He realized that the credibility of a company located in a developed market increases toward the market, so he selected Florida to establish the company. Emerging markets seek stability in advanced economies, in order to explore opportunities that are not present in the home country, facilitating their accelerated international expansion (Bangara et al., 2012).

Besides credibility, another relevant aspect in the IT area is trust, but the founder does not think the lack of both is because the company comes from an emerging market, he argues it is in virtue of the IT field. In order to overcome the lack of credibility and gain trust, the company shows the previous projects and portfolio to the clients, explaining the services. The founder is the first contact in the firm, he takes care of the internationalization and R\&D aspects of it. When the company internationalize and possess an entrepreneurial posture, it gets benefits with legitimacy and credibility, equally facilitates the development of new capabilities for international growth at lower risks (Zaheer, 1995; Zaheer \& Mosakowski, 1997). 
Tab. 3

The propositions' evidences

\begin{tabular}{|c|c|}
\hline Proposition & Evidences \\
\hline $\begin{array}{l}\text { Since internationalization can facilitate the access to new } \\
\text { resources, its effects also may increase the innovation } \\
\text { performance of firms. }\end{array}$ & $\begin{array}{l}\text { Proactive and Aggressive strategy; Competitive advantages; } \\
\text { Revenue growth; Quality; Knowledge; Experience; Stability. }\end{array}$ \\
\hline $\begin{array}{l}\text { BGs use their networks to target many countries and acquire } \\
\text { resources including innovations, in which they lead to } \\
\text { accelerated internationalization. }\end{array}$ & $\begin{array}{l}\text { Strong network; No previous international network; Facebook } \\
\text { and Meet up. }\end{array}$ \\
\hline $\begin{array}{l}\text { BGs from emerging markets seek for developed economies to } \\
\text { access resources and innovation in order to obtain legitimacy. }\end{array}$ & $\begin{array}{l}\text { Credibility and Reliability; No negative impact; Shows previous } \\
\text { projects and portfolio. }\end{array}$ \\
\hline
\end{tabular}

Source: Research data

The founder recommends studying about the immigration of the country and finding people who may help with the accounting process to have a safe internationalization.

The evidences from the propositions are presented in Table 3.

Since the company attained the competitive advantages associated to resources, knowledge, experience with its internationalization, it also was able to innovate in quality and processes achieving sales revenue growth.

Networks were crucial in this process of internationalization, they helped the firm with the market, institutions information and due to this the company was able to succeed and innovate the processes and services in the international market.

Entering a developed country, the firm could access new resources, improve the existing ones as well as innovate in the international country acquiring legitimacy in the market.

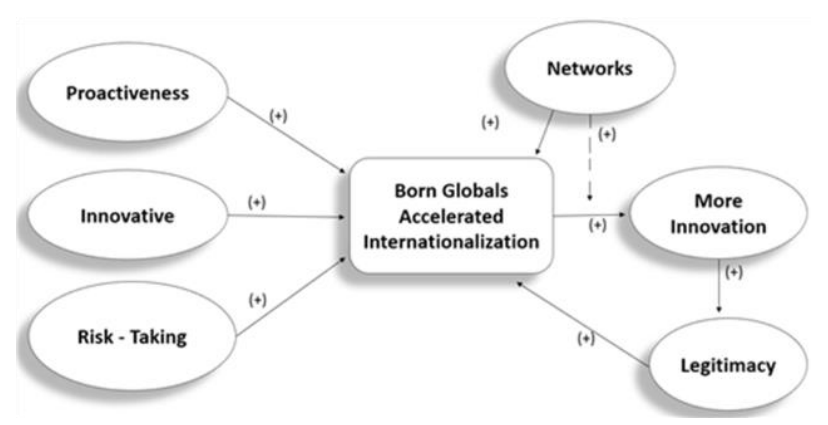

Fig. 2

Study's Framework

Source: Research data

This article is based on a single case study, which may limit a general conclusion that may apply for the phenomenon of Born Global. This is indeed a limitation of the study. However, since our purpose is to establish the connections between entrepreneurial behavior, network and innovation performance, we believe that the outcome of the study suggests the ways of such dimensions interact to promote innovation performance in the case of Born Global from an emerging economy. Figure 2 gives a better understanding of the study's results, we propose the following framework.

\section{CONCLUDING REMARKS}

The studies of BG phenomenon have had an increase in the 1990s, in distinct aspects and countries. When studying their determinants, there is a diversity between developed and emerging countries, although the main activity of this kind of firms has been the development of market knowledge, that they have achieved through their network ties.

These companies perform an interesting kind of business in consequence of their unique characteristic that are manifested in their early and fast internationalization, favoring especially smaller and innovative firms. They prefer to have personal contact to conduct their relationship with the relevant costumers and be able to perceive their costumer needs. These firms provide an impulse to the innovation and economic growth in any type of economy.

This study analyzed how the internationalization affects the innovation in a BG from Brazil. The main findings of this research are that, the internationalization of this BG from Brazil to the U.S.A benefits the company in different manners such as: economic growth, we could see that the company had a significant sales growth after the process; exploited resources, it had access to qualified 
resources and added value to its services and processes; enhanced knowledge; the firm showed more credibility towards other countries because of its presence in a developed economy; in addition, the company obtained more stability and reliability, and due to this it is able to make future plans.

Although, we believe that the entrepreneur and his previous global vision and experience are the main factors of this business. In consequence of these benefits, it is able to innovate in internal procedures and with better services to the clients. In this case study was observed that even if the BG is from an emerging market the lack of credibility and trust is a consequence of the IT field and not the market economy.

Other aspects as networks, finance, in this case service strategies, innovation, experience and knowledge are crucial issue for this process, we noticed that the BG innovativeness is the key element which expand firm performance. It is possible to affirm that the network after the internationalization process was relevant for the development and financial growth of the company, since the company did not have any network with the host country before the internationalization. In conclusion, the immigration and accounting were the hardest process the company found in the process.

This study attempted to contribute to the literature in the expansion of knowledge about the effects of the internationalization on innovation, also in verifying the entrance of a $B G$ from emerging market to a developed one, as well as the role of the host country institutions on the innovation.

The case of Brazil illustrates many of the aspects that are common to most emerging economies. First, because Born Global are relatively late comers among the focal firms in emerging economies, their internationalization path is constrained by weak institution in the home country. In addition, these firms have started to seek for a new approach of foreign markets to improve their economic growth but also to access specific institutional environment that may provide them with new resources and building new capabilities that may improve their innovation performance. Lastly, companies from emerging economies as shown by the Brazilian case, when adopting such strategy, they mostly attempt to settle in highly developed countries using their strong entrepreneurial behavior aiming at accessing other advantages and resources available to their networks.

It also has managerial contributions to this field, it evidences that the entrepreneur's vision, his networks and the institutions it accesses are fundamental to execute global strategies and acquire innovation, the same as the experience and industry knowledge before internationalizing.

Finally, the limitations of this work are associated to the lack of literature about emerging markets in this area and the fact that only two people were able to participate of the interview.

\section{REFERENCES}

- $\quad$ Abbott, P., Zheng, Y., Du, R., \& Willcocks, L. (2013). From boundary spanning to creolization: A study of Chinese software and services outsourcing vendors, 22(2), 121-136.

- $\quad$ Andersson, U., Dasí, À., Mudambi, R., \& Pedersen, T. (2016). Technology, innovation and knowledge: The importance of ideas and international connectivity. Journal of World Business, 51(1), 153-162.

- Autio, E., George, G., \& Alexy, O. (2011). International entrepreneurship and capability developmentqualitative evidence and future research directions. Entrepreneurship Theory and Practice, 35(1), 11-37.

- Axelsson, B., \& Easton, G. (Eds.). (2016). Industrial networks: a new view of reality. Routledge.

- $\quad$ Bangara, A., Freeman, S., \& Schroder, W. (2012). Legitimacy and accelerated internationalization: An Indian perspective. Journal of World Business, 47(4), 623-634.

- Bardin, L. (2010). Análise de conteúdo.(1977). Lisboa (Portugal): Edições, 70.

- Baum, M., Schwens, C., \& Kabst, R. (2013). International as opposed to domestic new venturing: The moderating role of perceived barriers to internationalization. International Small Business Journal, 31(5), 536-562.

- Bell, J. (1997). A comparative study of the export problems of small computer software exporters in Finland, Ireland and Norway. International Business Review, 6(6), 585-604.

- Boermans, M. A., \& Roelfsema, H. (2015). The effects of internationalization on innovation: Firm-level evidence for transition economies. Open Economies Review, 26(2), 333-350.

- Buckley, P. J. (2009a). Internalisation thinking: From the multinational enterprise to the global factory. International Business Review, 18, 224-235.

- Buckley, P. J. (2009b). The impact of the global factory on economic development. Journal of World Business, 44(2), 131-143. 
- Chandra, Y., Styles, C., \& Wilkinson, I. F. (2012). An opportunity-based view of rapid internationalization. Journal of International Marketing, 20(1), 74-102.

- Castaño, M. S., Méndez, M. T., \& Galindo, M. Á. (2016). Innovation, internationalization and business-growth expectations among entrepreneurs in the services sector. Journal of Business Research, 69(5), 1690-1695.

- Cavusgil, S. T., \& Knight, G. (2009). Born global firms: A new international enterprise. Business expert press.

- Cavusgil, S. T., \& Knight, G. (2015). The born global firm: An entrepreneurial and capabilities perspective on early and rapid internationalization. Journal of International Business Studies, 46(1), 3-16.

- Cavusgil, T., Knight, G., \& Riesenberger, J. (2012). International Business, Ed.

- Chen, Y. Y., \& Jaw, Y. L. (2014). How do business groups' small world networks effect diversification, innovation, and internationalization? Asia Pacific Journal of Management, 31(4), 1019-1044.

- Chetty, S. K.; StangI, L. M. (2010) Internationalization and innovation in a network relationship context. European Journal of Marketing, 44, 11/12, 1725-1743.

- Coviello, N. E. (2006). The network dynamics of international new ventures. Journal of International Business Studies, 37(5), 713-731.

- Creswell, J. W. (2013). Research design: Qualitative, quantitative, and mixed methods approaches. Sage publications.

- Cuervo-Cazurra, A. (2008). The multinationalization of developing country MNEs: The case of multilatinas. Journal of international Management, 14(2), 138-154.

- Cui, Y., Sun, C., Xiao, H., \& Zhao, C. (2016). How to become an excellent entrepreneur: The moderating effect of risk propensity on alertness to business ideas and entrepreneurial capabilities. Technological Forecasting and Social Change, 112, 171-177.

- Damanpour, F. (1991). Organizational innovation: A meta-analysis of effects of determinants and moderators. Academy of management journal, 34(3), 555-590.

- Damanpour, F., \& Aravind, D. (2012). Managerial innovation: Conceptions, processes, and antecedents. Management and Organization Review, 8(2), 423-454.

- Damanpour, F., \& Evan, W. M. (1984). Organizational innovation and performance: the problem of" organizational lag". Administrative science quarterly, 392-409.

- Dib, L. A., Da Rocha, A., \& Da Silva, J. F. (2010). The internationalization process of Brazilian software firms and the born global phenomenon: Examining firm, network, and entrepreneur variables. Journal of international entrepreneurship, 8(3), 233-253.

- Eisenhardt, K. M. (1989). Building theories from case study research. Academy of Management Review, 14(4), 532-550.
- Evanschitzky, H., Eisend, M., Calantone, R. J., \& Jiang, Y. (2012). Success factors of product innovation: An updated meta-analysis. Journal of Product Innovation Management, 29(S1), 21-37.

- Florida, R. (1997). The globalization of R\&D: Results of a survey of foreign-affiliated R\&D laboratories in the USA. Research policy, 26(1), 85-103.tung

- García-García, R., García-Canal, E., \& Guillén, M. F. (2017). Rapid internationalization and long-term performance: The knowledge link. Journal of World Business, 52(1), 97-110.

- Ghauri, P. (2004). Designing and conducting case studies in international business research. Handbook of qualitative research methods for international business, 109-124.

- Gunday, G., Ulusoy, G., Kilic, K., \& Alpkan, L. (2011). Effects of innovation types on firm performance. International Journal of production economics, 133(2), 662-676

- Hitt, M. A., Hoskisson, R. E., \& Kim, H. (1997). International diversification: Effects on innovation and firm performance in product-diversified firms. Academy of Management Journal, 39, 1084-1119.

- Johanson, J., \& Vahlne, J.E. (1977). The internationalization process of the firm. A model of knowledge development and increasing foreign market commitments. Journal of International Business Studies, 8(1), 23632.

- Johanson, J., \& Vahlne, J.E. (1990). The mechanism of internationalisation. International marketing review, 7(4).

- Johanson, J., \& Vahlne, J.E. (2009). The Uppsala internationalization process revisited: From liability of foreignness to liability of outsidership. Journal of International Business Studies, 40(9), 141161431

- Hisrich, R. D., \& Peters, M. P. (2004). Empreendedorismo (5a ed.). Porto Alegre: Bookman.

- Karagozoglou, N. and Lindell, M. (1998). "Internationalization and small and medium sized technology-based firms: an exploratory study". Journal of Small Business Management, Vol. 36 No. 1, pp. 4459.

- $\quad$ Kim, D., Basu, C., Naidu, G. M., \& Cavusgil, E. (2011). The innovativeness of born-globals and customer orientation: Learning from Indian born-globals. Journal of Business Research, 64(8), 879-886.

- Knight, G. A., \& Cavusgil, S. T. (2004). Innovation, organizational capabilities, and the born-global firm. Journal of International Business Studies, 35(2), 124141.

- $\quad$ Kotabe, M., Srinivasan, S.S., Aulakh, P.S., (2002). Multinationality and firm performance: the moderating role of R\&D and marketing capabilities. Journal of International Business Studies 33 (1), 79-97.

- Kyläheiko, K., Jantunen, A., Puumalainen, K., Saarenketo, S., \& Tuppura, A. (2011). Innovation and 
internationalization as growth strategies: The role of technological capabilities and appropriability. International Business Review, 20(5), 508-520.

- Li, J., \& Rugman, A. M. (2007). Real options and the theory of foreign direct investment. International Business Review, 16(6), 687-712.

- Li, J., Vertinsky, I., \& Zhang, H. (2013). The quality of domestic legal institutions and export performance. Management international review, 53(3), 361-390.

- Lobo, S., \& Whyte, J. (2017). Aligning and Reconciling: Building project capabilities for digital delivery. Research Policy, 46(1), 93-107.

- Lu, J. W., \& Beamish, P. V. (2001). The internationalization and performance of SMEs. Strategic Management Journal, 22(6/7), 565-586.

- Luo, Y., Xue, Q., \& Han, B. (2010). How emerging market governments promote outward FDI: Experience from China. Journal of world business, 45(1), 68-79.

- Lou, Y., \& Tung, R. L. (2007). International expansion of emerging market enterprises: A springboard perspective. Journal of International Business Studies, 38: 481-498.

- Lumpkin, G. T., \& Dess, G. G. (1996). Clarifying the entrepreneurial orientation construct and linking it to performance. Academy of management Review, 21(1), 135-172.

- Madhok, A. (2009). Overcoming the liability of emergingness through internationalization by acquisition: Learning and competitive catch-up by emerging multinationals. Unpublished Working Paper. York University.

- Markman, G. D., \& Baron, R. A. (2003). Personentrepreneurship fit: why some people are more

- successful as entrepreneurs than others. Human Resource Management Review, 13(2), 281-301.

- Matsuo, M. (2006). Customer orientation, conflict, and innovativeness in Japanese sales departments. Journal of Business Research, 59(2), 242-250.

- McDougall, P. P., \& Oviatt, B. M. (2000). International entrepreneurship: The intersection of two research paths. Academy of Management Journal, 43(5), 902906.

- Monferrer Tirado, D., Blesa Pérez, A., \& Ripollés Meliá, M. (2014). Born globals trough knowledge-based dynamic capabilities and network market orientation.

- Mudambi, R., \& Zahra, S. A. (2007). The survival of international new ventures. Journal of International Business Studies, 38(2), 333-352.

- Narula, R., \& Hagedoorn, J. (1999). Innovating through strategic alliances: Moving towards international partnerships and contractual agreements. Technovation, 19(5), 283-294.
- Nelson, R. R.; Winter, S. G. (1982). An evolutionary theory of economic change. Cambridge, Harvard University Press.

- North, D. C. (1990). Institutions, institutional change and economic performance: Cambridge university press.

- Pearce, R., \& Papanastassiou, M. (2006). To 'almost see the world': Hierarchy and strategy in Hymer's view of the multinational. International Business Review, 15(2), 151-165.

- Picken, J. C. (2017). From founder to CEO: An entrepreneur's roadmap. Business Horizons, 60(1), 714.

- Porter, M. E. (1990). The competitive advantage of nations. Harvard business review, 68(2), 73-93.

- Rennie, M. W. (1993). Born global. McKinsey Quarterly, 4, 45-52.

- Ribeiro, F. C. F., Scholar, V., Junior, M. D. M. O., \& Borini, F. M. (2012). Born Globals from Emerging Economies: Small and Medium Brazilian TechnologyBased Firms.

- Ribeiro, F. C. F., \& PIMENTEL, J. (2009). Empresas born globals brasileiras: a influência do perfil do empreendedor e da localização geográfica. XXXIII Encontro da ANPAD, São Paulo.

- Rubach, S. (2013). Collaborative regional innovation initiatives: a booster for local company innovation processes? Systemic practice and action research, 26(1), 3-21.

- Schumpeter, J. A. (1934). The theory of economic development: An inquiry into profits, capital, credit, interest, and the business cycle (Vol. 55). Transaction publishers.

- Scott, W. R. (1995). Institutions and organizations (Vol. 2). Thousand Oaks, CA: Sage.

- Shearmur, R. (2011). Innovation, regions and proximity: from neo-regionalism to spatial analysis. Regional Studies, 45(9), 1225-1243.

- $\quad$ Smallbone, D., Leig, R., \& North, D. (1995). The characteristics and strategies of high growth SMEs. International Journal of Entrepreneurial Behavior \& Research, 1(3), 44-62.

- $\quad$ Tracey, P., \& Phillips, N. (2011). Entrepreneurship in emerging markets. Management International Review, 51(1), 23-39.

- Tung, R. L. (2007). The human resource challenge to outward foreign direct investment aspirations from emerging economies: The case of China. The International Journal of Human Resource Management, 18(5), 868-889.

- Varis, M., \& Littunen, H. (2010). Types of innovation, sources of information and performance in entrepreneurial SMEs. European Journal of Innovation Management, 13(2), 128-154. 
- Wictor, I. (2012). Born globals: rapid international growth in new ventures.

- Wright, Filatotchev, Hoskisson, \& Peng (2005). Strategy research in emerging economies: Challenging the conventional wisdom. Journal of management studies, 42(1), 1-33.

- Wu, J., Wang, C., Hong, J., Piperopoulos, P., \& Zhuo, S. (2016). Internationalization and innovation performance of emerging market enterprises: The role of host-country institutional development. Journal of World Business, 51(2), 251-263.

- Yin, R. K. (1989). Research design issues in using the case study method to study management information systems. The information systems research challenge: Qualitative research methods, 1, 1-6.

- Yin, R. K. (2009). Case study research: Design and methods 4th ed. In United States: Library of Congress Cataloguing-in-Publication Data.

- Zahra, S. A., \& Covin, J. G. (1995). Contextual influences on the corporate entrepreneurship-performance relationship: A longitudinal analysis. Journal of business venturing, 10(1), 43-58.

- Zaheer, S. (1995). Overcoming the liability of foreignness. Academy of Management journal, 38(2), 341-363.

- Zaheer, S. (2002). The liability of foreignness, redux: A commentary. Journal of International Management, 8(3), 351-358.

- Zaheer, S., \& Mosakowski, E. (1997). The dynamics of the liability of foreignness: A global study of survival in financial services. Strategic management journal, 18(6), 439-463.

- Zander, I., McDougall-Covin, P., \& Rose, E. L. (2015). Born globals and international business: Evolution of a field of research. Journal of International Business Studies, 46(1), 27-35.

- Zimmerman, M. A., \& Zeitz, G. J. (2002). Beyond survival: Achieving new venture growth by building legitimacy. Academy of Management Review, 27(3), 414-431.

\section{ABOUT THE AUTHORS}

- Thaisa Carolina Zonta holds a Graduation Degree in International Business Technology and Master's in Business Administration by FURB/SC. E-mail: thaisaczonta@gmail.com

- Mohamed Amal is Economist and PHD in industrial engineering by the UFSC/Brazil. Post doc at Columbia University New York/USA. Associate professor of economics and International Business at the Regional University of Blumenau. E-mail: mohamedamal.amal@gmail.com 


\title{
Internacionalização e inovação: O caso de uma born global do Brasil
}

\author{
Thaisa Carolina Zonta e Mohamed Amal
}

Universidade Regional de Blumenau, FURB/PPGAD, Blumenau SC, Brasil

\section{DETALHES DO ARTIGO}

\section{Histórico do Artigo:}

Recebido: 23 de Maio de 2017

Revisado: 07 de Outubro de 2017

Aceito: 29 de Janeiro de 2018

Disponível online: 10 de Abril de 2018

Sistema de revisão "Double blind review"

Editor Científico

Mariana Sutter

\section{Palavras-chaves:}

Born Globals

Países Emergentes

Instituições

Internacionalização

Inovação

\section{RESUMO}

\begin{abstract}
A relevância do estudo sobre Born Globals está aumentando devido seus aspectos de internacionalização no estágio inicial, inovação e crescimento econômico; entretanto, a maioria dos estudos existentes estão focados nos mercados desenvolvidos. Assim sendo, este estudo analisa os efeitos da internacionalização sobre a inovação de uma empresa Born Global de mercado emergente. Utilizou-se a revisão da literatura sobre inovação, internacionalização e Born Globals de mercados emergentes, também entrevista em profundidade com o fundador e a coordenadora financeira/administrativa de uma empresa Born Global brasileira. A qual demonstrou um comportamento proativo de internacionalização aos Estados Unidos. O resultado mostra que a internacionalização a um país com instituições estáveis afeta positivamente a inovação da empresa, possibilitando a exploração de recursos, crescimento financeiro, outrossim conhecimento e capacidades superiores. Esta pesquisa contribui para um melhor conhecimento do fenômeno no contexto dos mercados emergentes. Além disso, a perspectiva das instituições no país de acolhimento, que determina o desempenho de inovação da empresa e, finalmente, explorar o caso de uma empresa de economia emergente que se mudou para um país desenvolvido (Sul-Norte) para desenvolver novas capacidades e manter sua estratégia de inovação.
\end{abstract}

(C) 2018 Internext | ESPM. Todos os direitos reservados!

To cite this article:

Zonta, T. C. and Amal. M. (2018) Internationalization and innovation: The case of a born global from Brazil. Internext - Revista Eletrônica de Negócios Internacionais, 13 (1), 63-76. DOI:

http://dx.doi.org/10.18568/1980-4865.13163-76

For access this article: http://dx.doi.org/ 10.18568/1980-4865.13163-76 